\title{
A Single Phase Grid Connected PV System working in Different Modes
}

\author{
Pritee S. Gotekar \\ Electrical Engineering Department \\ Priyadarshini College of Engineering \\ Nagpur, India \\ p_somkuwar@yahoo.com
}

\author{
S. P. Muley \\ Electrical Engineering Department, \\ Priyadarshini College of Engineering, \\ Nagpur, India \\ muleyshubhada68@gmail.com
}

\author{
D. P. Kothari \\ Gaikwad Patil Group of Institutions \\ Nagpur, India \\ dpkvits@gmail.com
}

\begin{abstract}
The current grid standards for the single-phase residential PV system expect it to operate at Maximum Power Point Tracking (MPPT) mode under normal operating conditions and to maintain the voltage profile whenever a grid fault occurs. The proposed system supplies power to the load under stable conditions and the PV system works in MPPT mode. When the fault occurs at the Point of Common Coupling (PCC) and the voltage is reduced, the proposed controller maintains the voltage profile by injecting the current fed by the current controller at the PCC. The controller shifts from MPPT to the faulty mode and maintains voltage as per grid requirements. During islanding conditions, the PV system successfully caters to the requirements of the load by shifting the control from MPPT to islanding mode. When the PV system is in operation the power quality is enhanced.
\end{abstract}

Keywords-maximum power point tracking (MPPT); photovoltaic $(P V)$ systems; perturb and observe (P and $O)$; point of common coupling(PCC)

\section{INTRODUCTION}

Due to the incessant reduction of the photovoltaic (PV) module price and to the increase of the pursuit for eco-friendly energy systems, there is a spurt in the demand for solar PVs. The future PV systems would have to fulfill the requirements for the generation closer to the consumption points [1,2]. The PV modeling technique and implementation of fuzzy based MPPT systems to track maximum power efficiently is explained in [3-4]. The precise control of the duty cycle with respect to various atmospheric conditions is obtained in [5]. A peak current controller strategy is used to generate the gate pulses of semiconductor switches which control both active and reactive powers [6-8]. PV systems in the future should perform a number of functions like reactive power control, Maximum Power Point Tracking (MPPT), islanding detection, power quality improvement and Fault Ride-Through (FRT) capability [9-11]. Phase, amplitude, and frequency of the grid voltage are key information for the operation of inverter systems connected to the grid. In grid-connected inverters, the correct and accurate detection of the phase angle, amplitude and frequency of the grid voltage are essential in ensuring the correct generation of reference signals and to meet future standards, which can be estimated using a Phase-Locked Loop (PLL) [12-13].
Power electronic devices draw large amounts of reactive power and inject harmonics in the network [14]. A multilevel single phase inverter using PI controller is used to improve power quality in [15]. Voltage sag occurrence is a common issue which may cause unnecessary tripping in the case of a single phase system that is working in grid connected or islanded mode [16-17]. To address the reactive power control issue caused by the use of loads which affects the current being drawn from the source, a PV system is used in [18]. In islanding mode, the amplitudes and waveforms of load voltages are maintained sinusoidal by the voltage controller. The transfer of modes (islanded to grid connected and vice-versa) is implemented using the synchronization controller as per the accessibility of the grid [19-21].

The objective of the proposed research is to design a single phase grid connected PV system. The key contributions of this paper are:

- The design of a PV system depending upon the load requirements using Perturb and Observe $(\mathrm{P}$ and $\mathrm{O})$ for MPPT.

- A DC-DC boost controller is proposed to maintain the output voltage constant.

- The implementation of a PV system controller capable to supply active and reactive power during normal operating conditions.

- The proposed controller injects reactive current when fault occurs at the Point of Common Coupling (PCC) during voltage sag conditions.

- The PV system needs to operate in islanded mode.

\section{SYSTEM CONFIGURAtION}

Figure 1 shows the block diagram of the system under consideration. The PV system is configured as dual stage with PV system connected to the PCC through DC-DC boost controller and inverter with the grid. This system operates in two modes, grid connected and islanded mode. The block diagram includes the PV array, the boost converter, an inverter, and the power control system [10]. 


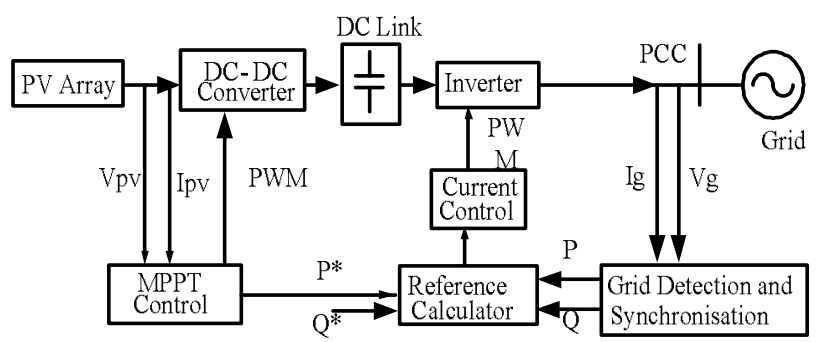

Fig. 1. Block diagram of the system.

\section{REACTIVE POWER CONTROL}

Under normal conditions, the PV system is operating in MPPT mode in order to supply as much energy as possible to the grid. As per the grid requirements, when fault occurs at PCC, the PV inverter should inject reactive current to bolster up the grid voltage. The control system consists of the MPPT, an Orthogonal Signal Generator (OSG) unit, controllers to generate current reference generation, and a PWM generation block. As the inverter output voltage is nonsinusoidal, a lowpass filter is connected between the inverter and the grid. $I_{g \alpha}$ and $I_{g \beta}$ represent the grid currents in the ' $\alpha \beta$ ' frame and $V_{g \alpha}$ and $\mathrm{V}_{\mathrm{g} \beta}$ represents grid voltage in the same frame. Equations $(1)$ and $(2)$ represent active power $(\mathrm{P})$ and reactive power $(\mathrm{Q})$ [11]. The current references are generated using PI controllers

$$
\begin{aligned}
& \mathrm{P}=\frac{1}{2}\left(\mathrm{~V}_{\mathrm{g} \alpha} * \mathrm{I}_{\mathrm{g} \alpha}+\mathrm{I}_{\mathrm{g} \beta} * \mathrm{~V}_{\mathrm{g} \beta}\right) \\
& \mathrm{Q}=\frac{1}{2}\left(\mathrm{~V}_{\mathrm{g} \alpha} * \mathrm{I}_{\mathrm{g} \alpha}-\mathrm{I}_{\mathrm{g} \beta} * \mathrm{~V}_{\mathrm{g} \beta}\right)
\end{aligned}
$$

\section{A. PV System}

A PV system consists of PV modules connected in series and in parallel depending upon DC system voltage and power. The peak value of product of voltage and current represents the Maximum Power Point (MPP) $\mathrm{P}_{\max }$. To extract maximum power from the given irradiance conditions the solar module should always be operated within that region. The implemented technique to extract that point is $\mathrm{P}$ and $\mathrm{O}$. A $2 \mathrm{~kW}$ PV system is considered. The system parameters are indicated in Table I.

\begin{tabular}{|c|c|c|}
\hline Sr No & Device & Components \\
\hline 1 & DC link capacitor & $\begin{array}{c}\mathrm{C}=2500 \mu \mathrm{F} \\
\text { reference voltage }=350 \mathrm{~V}\end{array}$ \\
\hline 2 & Boost converter & $\begin{array}{c}\mathrm{L}=2.9 \mathrm{mH}, \mathrm{C}=70 \mu \mathrm{F} \\
\text { switching frequency }=5 \mathrm{kHz}\end{array}$ \\
\hline 3 & LC filter & $\mathrm{L}=0.1 \mathrm{mH}, \mathrm{C}=100 \mu \mathrm{F}$ \\
\hline 4 & $\begin{array}{c}\text { Linear load } \\
\text { Non linear load }\end{array}$ & $\begin{array}{l}1 \mathrm{~kW} \text { and } 500 \mathrm{VAR} \\
1 \mathrm{~kW} \text { and } 500 \mathrm{VAR}\end{array}$ \\
\hline 5 & Source & $230 \mathrm{~V}(\mathrm{rms}), 50 \mathrm{~Hz}$ \\
\hline
\end{tabular}

TABLE I. SYSTEM PARAMETERS

\section{B. Boost Converter}

It is used to step up the input voltage and MPP. The main equations used for analysis are (3)-(5) [2] and the nomenclature is given in Table II.

$$
\begin{gathered}
\mathrm{M}=\frac{\mathrm{V}_{\mathrm{o}}}{\mathrm{V}_{\mathrm{d}}}=\frac{1}{(1-\mathrm{D})} \\
\mathrm{L}=\frac{\operatorname{Vin} * \text { Ton }}{\Delta \mathrm{I}}
\end{gathered}
$$

$$
\mathrm{C}_{\mathrm{DC}}=\frac{\mathrm{P}_{\mathrm{DC}}}{\left(2 *\left(\omega * \mathrm{~V}_{\mathrm{DC}} * \Delta \mathrm{V}_{\mathrm{DC}}\right)\right.}
$$

where $\mathrm{M}$ is the modulation index, $\mathrm{V}_{\text {in }}$ is the input voltage, $\mathrm{L}$ is the boost inductance and $\mathrm{C}$ is the capacitance of the boost converter.

\section{Synchronisation}

To assist the computation of active power $(\mathrm{P})$ and reactive power (Q) and for proper grid synchronization, the OSG is used. P and Q are calculated by using the OSG system whereas $\mathrm{T} / 4$ delay PLL is considered in this research. The OSG for single phase system is indicated in Figure 2 and the Simulink model is shown in Figure 3.

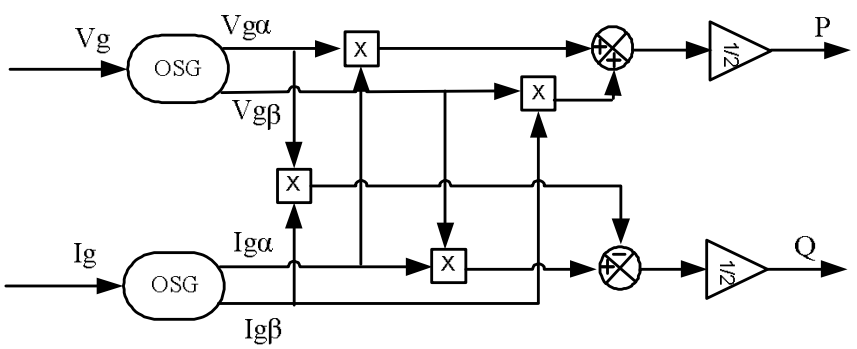

Fig. 2. Orthogonal signal generation for a single phase system.

The reactive power injection depends upon:

$$
\mathrm{I}_{\mathrm{p}}^{2}+\mathrm{I}_{\mathrm{q}}^{2}=\mathrm{I}_{\mathrm{N}}^{2} \leq \operatorname{Imax}
$$

The minimum reactive current $\left(\mathrm{I}_{\mathrm{q}}\right)$ to be injected to the grid is given by (7). Active power is restored to maintain the frequency limits, based on the peak value of (8).

$$
\begin{aligned}
& \mathrm{Iq}=\left\{\begin{array}{r}
\text { Deadband, } 0.9 \leq \frac{\mathrm{Vg}}{\mathrm{V}_{\mathrm{N}}} \leq 1 \\
2 \mathrm{x} \frac{\mathrm{Vg}}{\mathrm{Vn}} \mathrm{xI}_{\mathrm{N}}, \quad 0.5 \leq \frac{\mathrm{Vg}}{\mathrm{V}_{\mathrm{N}}} \leq 0.9 \\
\mathrm{I}_{\mathrm{N}}, \quad 0.1 \leq \frac{\mathrm{Vg}}{\mathrm{V}_{\mathrm{N}}} \leq 0.5
\end{array}\right.
\end{aligned}
$$

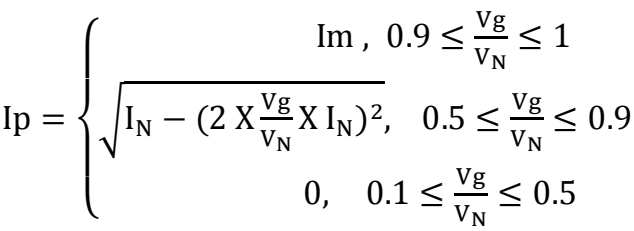

The quality of power to be injected to the grid depends on the current controller. The exquisite design of filters and selection of harmonics compensators is prerequisite of power quality. The gain of the Proportional Resonant (PR) and Harmonic Compensator (HC) control in the $\alpha \beta$ reference frame is shown in (9) and (10):

$$
\begin{gathered}
\left(G_{P R}(s)\right)=K_{P}+\frac{K_{\mathrm{i}} s}{s^{2}+\left(\oplus_{0}\right)^{2}} \\
\left(G_{H C}(s)\right)=\frac{K_{i h} s}{s^{2}+\left(h \omega_{0}\right)^{2}}
\end{gathered}
$$




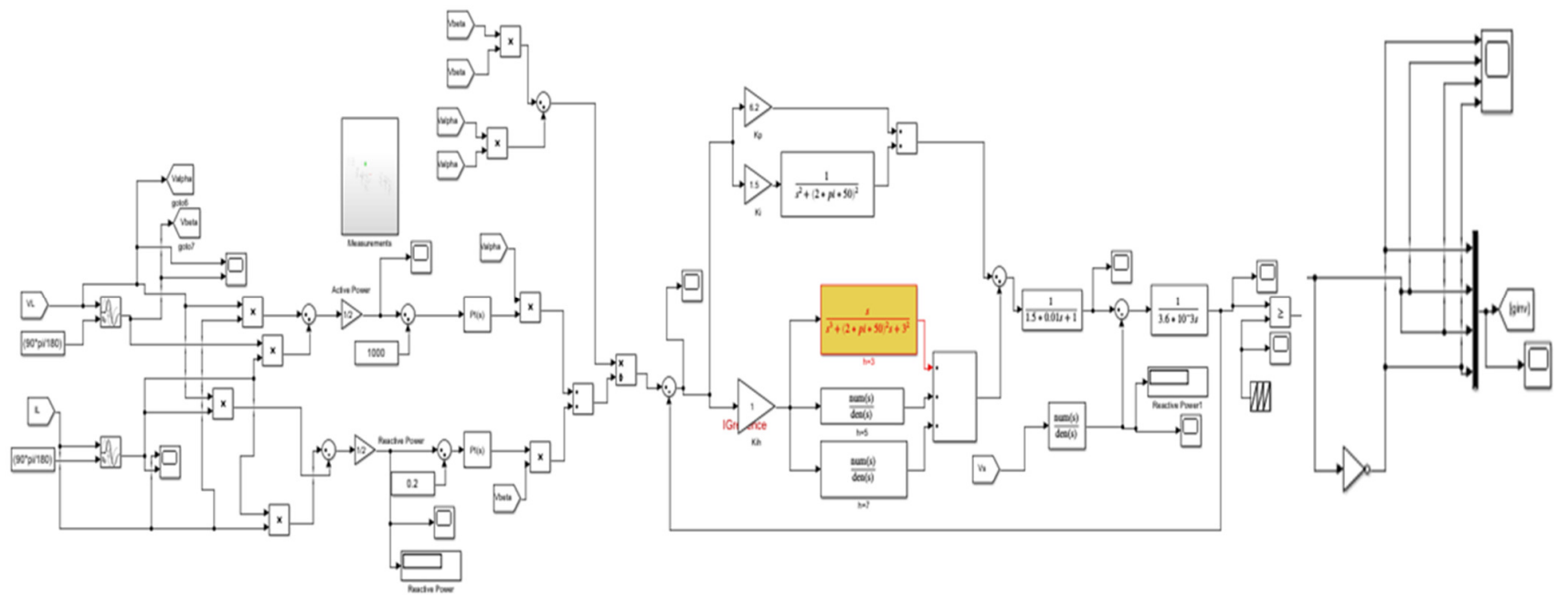

Fig. 3. OSG transformation and $\mathrm{G}_{\mathrm{PR}+\mathrm{HC}}$ controller.

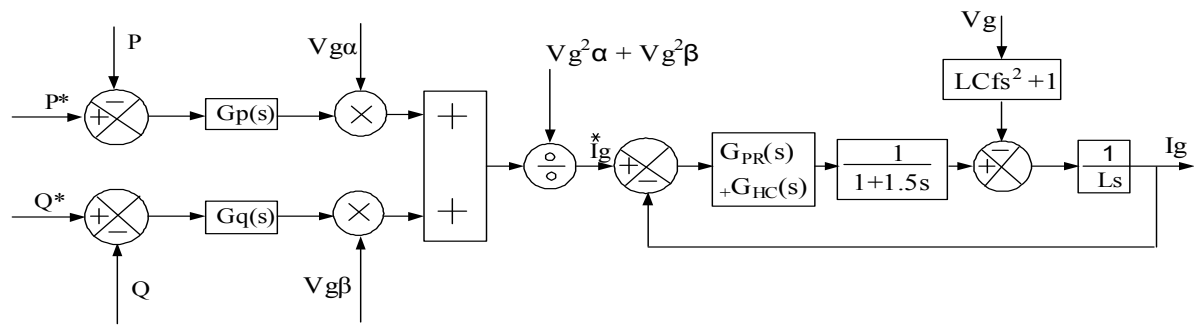

Fig. 4. Control diagram of single phase grid connected PV system based on PQ theory.

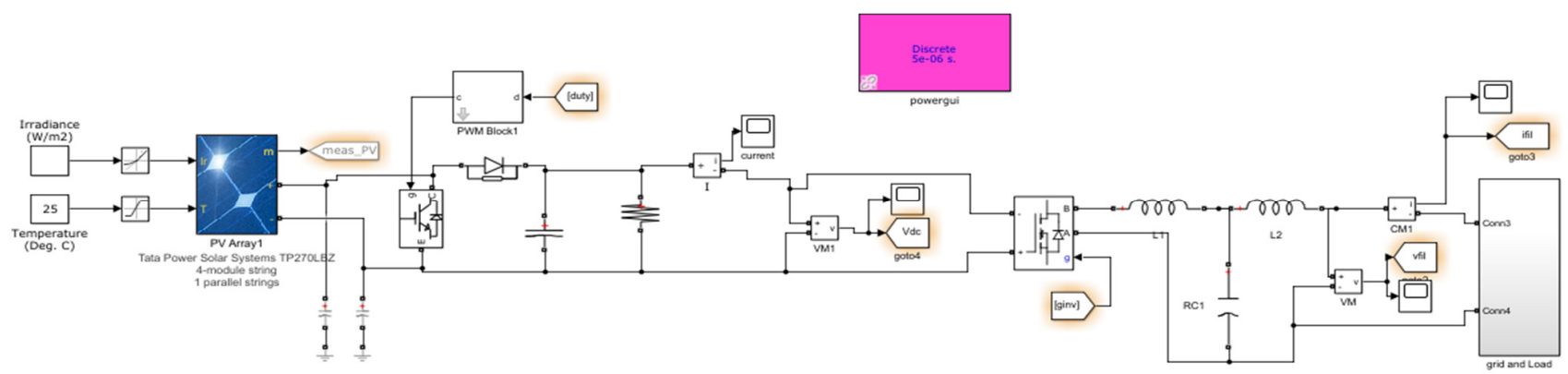

Fig. 5. Simulink model of the PV system connected to load and grid.

TABLE II. NOMENCLATURE

\begin{tabular}{|c|c|c|c|}
\hline Symbol & Description & Symbol & Description \\
\hline & Proportional gain & $\mathrm{V}_{\mathrm{g}}$ & Voltage of the grid \\
\hline $\mathrm{L}$ & Inductance of the DC-DC boost converter & $\mathrm{T}_{\mathrm{on}}$ & Time during which the semiconductor switch of the boost converter is ON \\
\hline $\mathrm{P}_{\mathrm{PV}}$ & Power output of the PV system during faulty conditions & $\mathrm{V}$ & Grid instantaneous voltage \\
\hline $\mathrm{I}_{\max }$ & Maximum power point current from PV & $\mathrm{Iq}$ & Reactive current requirements of the grid \\
\hline $\mathrm{Ip}$ & Active current requirements of the grid & $\mathrm{P}_{\mathrm{MPP}}$ & Maximum power output of the PV system \\
\hline $\mathrm{I}_{\mathrm{g}}$ & Current of the grid & $\mathrm{I}_{\mathrm{N}}$ & Nominal inverter current \\
\hline $\mathrm{V}_{\mathrm{N}}$ & Nominal grid voltage & $\mathrm{K}_{\mathrm{ih}}$ & Harmonic compensator gain \\
\hline $\mathrm{C}_{\mathrm{DC}}$ & DC link capacitance & $\mathrm{D}$ & Duty cycle of the DC-DC boost converter \\
\hline$\Delta \mathrm{I}$ & Allowed current ripple (10\%) & $\mathrm{P}^{*}$ & Reference active power \\
\hline $\mathrm{P}_{\mathrm{DC}}$ & Average power of DC Link & $\mathrm{Q}^{*}$ & Reference reactive power \\
\hline $\mathrm{V}_{\mathrm{DC}}$ & Average voltage of DC Link & $\omega$ & Frequency of grid (r/s) \\
\hline$\Delta \mathrm{V}_{\mathrm{DC}}$ & Amplitude of voltage ripple & $\mathrm{C}$ & Capacitance of the filter \\
\hline $\mathrm{G}_{\mathrm{P}}(\mathrm{s})$ & PI controller for active power & $\mathrm{G}_{\mathrm{q}}(\mathrm{s})$ & PI controller for reactive power \\
\hline
\end{tabular}


$\mathrm{G}_{\mathrm{PR}}(\mathrm{s})$ is the transfer function of PR controller while $\mathrm{G}_{\mathrm{HC}}(\mathrm{s})$ is the transfer function of the harmonic compensator. The combination of $\mathrm{PR}$ and $\mathrm{HC}$ is involved to obtain a better control during dynamic conditions when operating mode switches from MPPT to low voltage ride through. The current controller is shown in Figure 4 and the Simulink model is shown in Figure 5.

\section{SimUlation RESUlTS}

System parameters are given in Table II. Figure 6 shows the $\mathrm{P}-\mathrm{V}$ curves for the given system. It is observed that MPP changes with change in irradiance. It is shown that the grid is supplying power to the load until $\mathrm{t}=1 \mathrm{~s}$. At this instant, a fault occurs and the PV system completely starts supplying power to the load. Various conditions were considered for the simulations in Simulink.
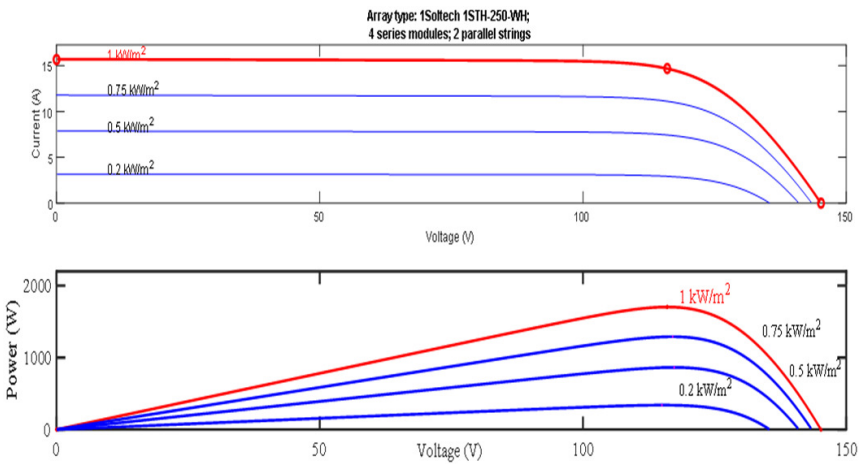

Fig. 6. PV curves for varying irradiance

\section{A. Load Supplied by Source}

The simulation was run for $1.5 \mathrm{~s}$. Figure 7 shows the DC link voltage across a capacitor which is maintained constant at $350 \mathrm{~V}$. Initially up to $1 \mathrm{~s}$ only the grid was acting as a source, supplying power to the linear load as shown in Figure 8. Power supplied to the linear and nonlinear load is shown in Figure 9.

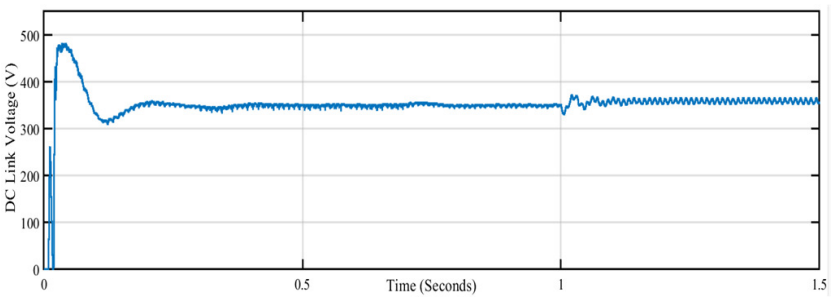

Fig. 7. DC Link Voltage

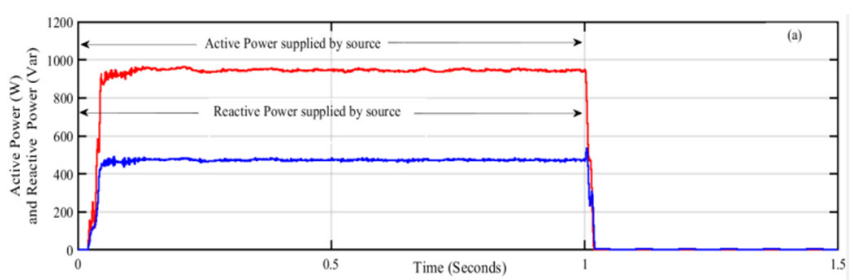

Fig. 8. Active and reactive power of linear load.

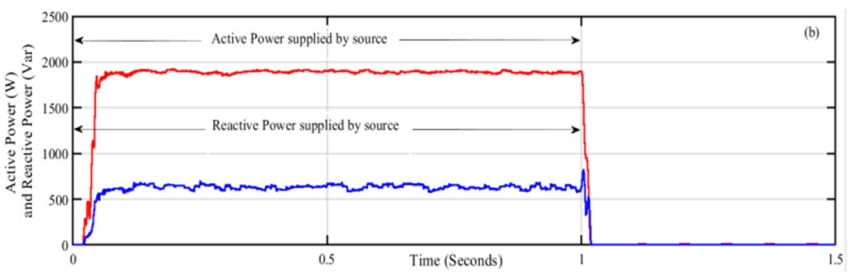

Fig. 9. Active and reactive power of linear and nonlinear load.

\section{B. Load Supplied by the Source and the PV System}

A combination of linear and nonlinear load is supplied up to $1 \mathrm{~s}$ to the source. Due to the occurrence of fault at PCC at $\mathrm{t}=1 \mathrm{~s}$, when the source fails to fulfill the requirements of the load, the PV system starts supplying power after $\mathrm{t}=1 \mathrm{~s}$. The simulation is run for $1.5 \mathrm{~s}$ as shown in Figure 10.

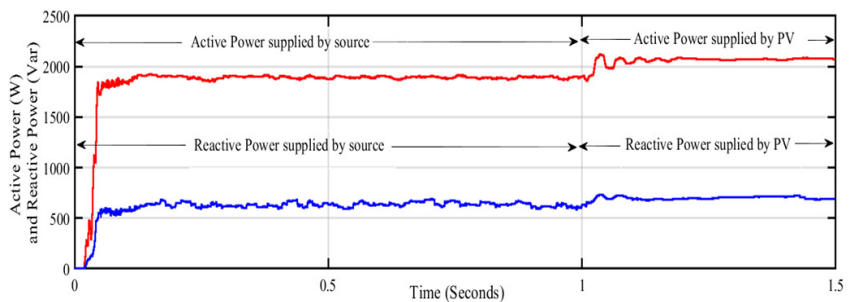

Fig. 10. Load supplied by the source and the PV system.

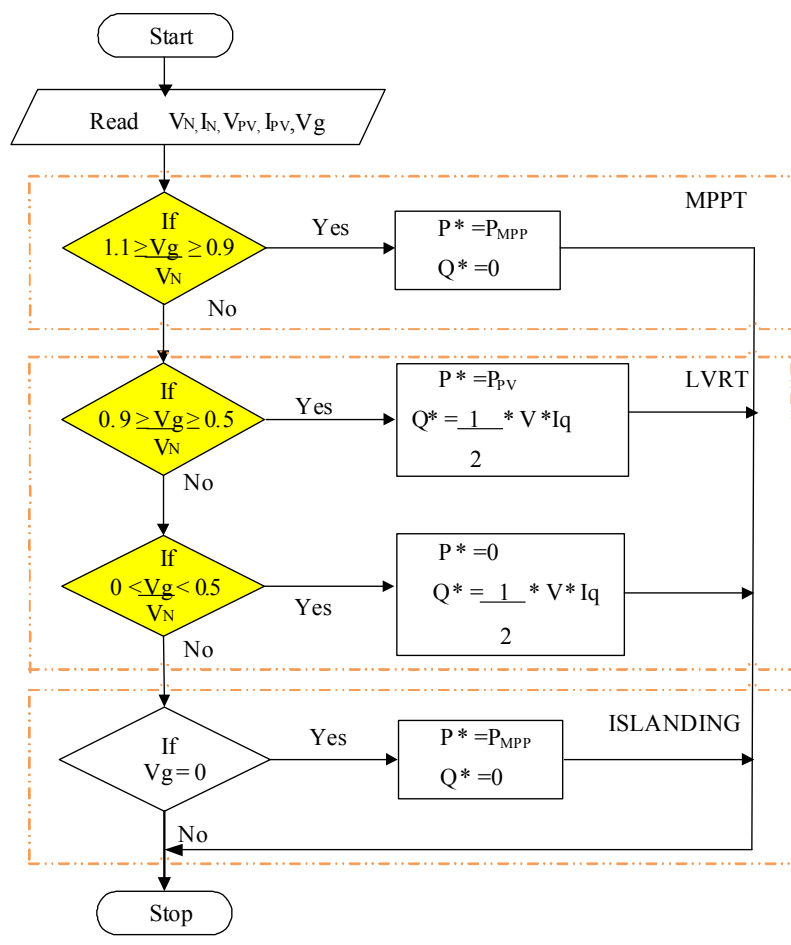

Fig. 11. Flowchart for reference power generation.

\section{Islanding}

A single phase double stage PV system is subjected to fault at $\mathrm{t}=1 \mathrm{~s}$. When the fault occurs at PCC and the grid is disconnected, fulfilling the load demand by PV will be a 
priority. The power requirement of the load is supplied by the PV system in islanded mode. The generated PV power is sufficient to supply the load. The prime concern is to disconnect the grid and use the photovoltaic system power as it is available. During islanding, the MPPT mode is switched to fault operating mode as shown in the flowchart of Figure 11. The source voltage during the fault is shown in Figure 12 and active and reactive power supplied to the linear and nonlinear load are given in Figure 13 respectively.

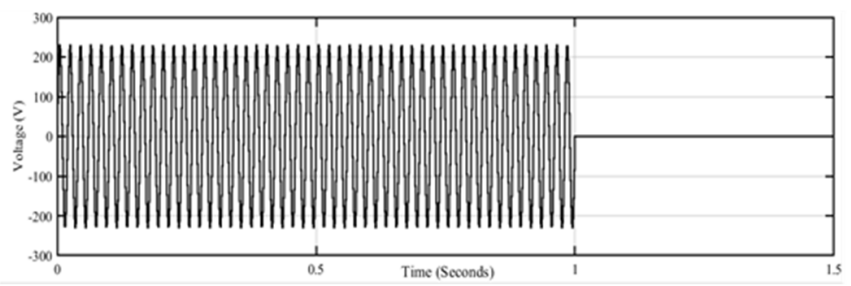

Fig. 12. Source voltage when fault occurs to $t=1 \mathrm{~s}$.

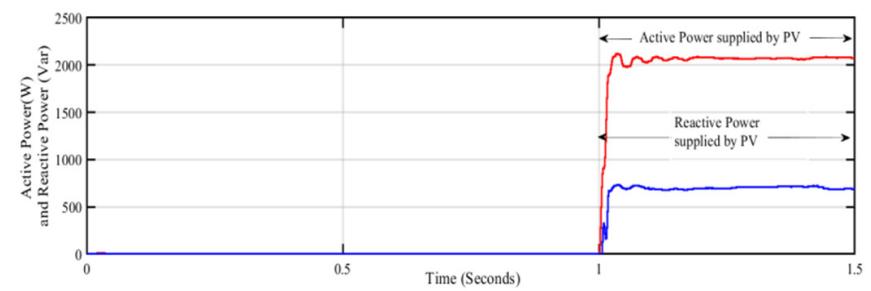

Fig. 13. Active and reactive power supplied during islanding.

\section{Voltage Sag}

Due to the occurrence of fault, a voltage sag appears at $\mathrm{t}=0.3 \mathrm{~s}$ and continues until $\mathrm{t}=0.7 \mathrm{~s}$. During this period, the system is shifted to fault mode and although the source voltage sags as shown in Figure 14, the current controller injects reactive current for compensation as per grid requirements.

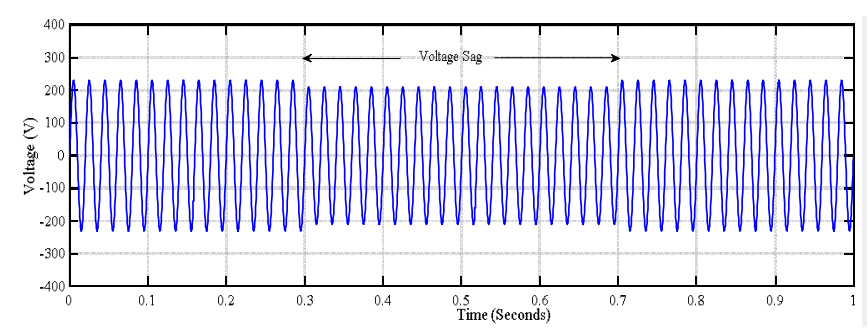

Fig. 14. Source voltage during sag from $\mathrm{t}=0.3 \mathrm{~s}$ to $\mathrm{t}=0.7 \mathrm{~s}$.

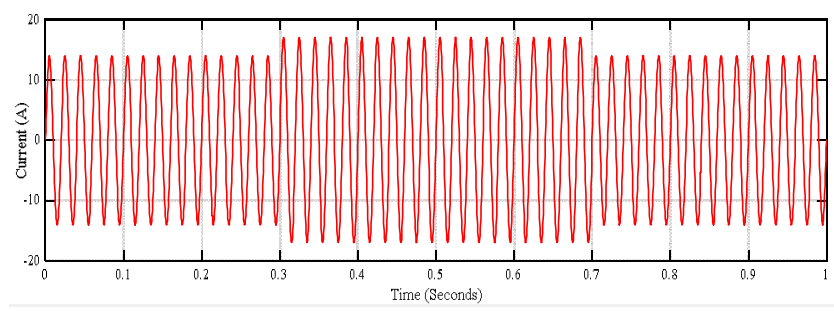

Fig. 15. Current supplied by the current controller.
When the sag occurs the load voltage remains unaltered due to the compensating current supplied by the inverter given by Figure 15. It is clear that during voltage sag conditions, the load voltage and hence the supply to the load is maintained by the PV system. Figure 16 shows the active and reactive powers during this period.

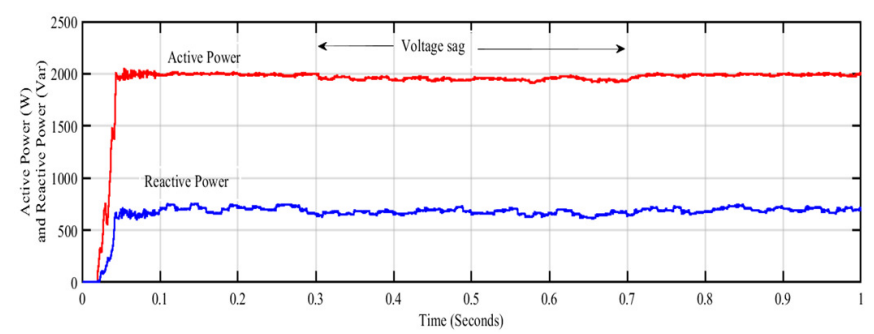

Fig. 16. Active and reactive power during the voltage sag.

\section{E. FFT Analysis}

Figure 17 shows the load current. The FFT analysis shows that THD is $17.74 \%$ (Figure 18) when the source is supplying the load, i.e before $\mathrm{t}=1 \mathrm{~s}$, but when the PV system supplies the load after the occurrence of fault at $\mathrm{t}=1 \mathrm{~s}$, the THD is reduced to $4.07 \%$ as shown in Figure 19.

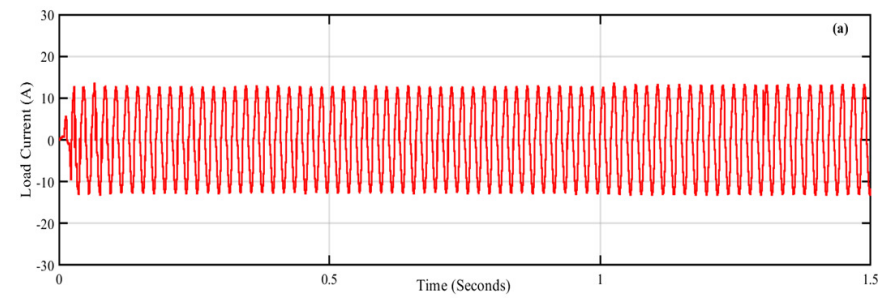

Fig. 17. Load current

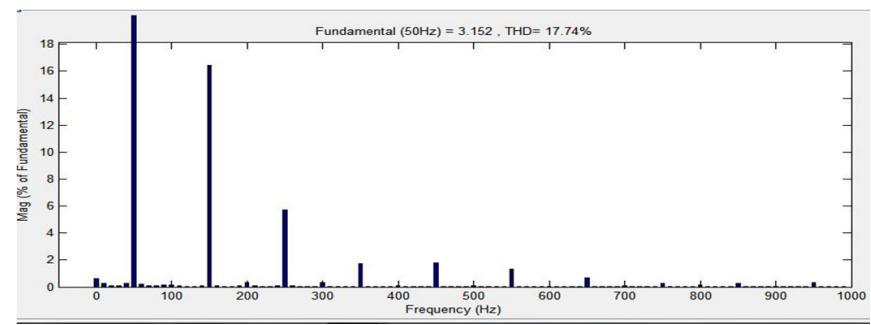

Fig. 18. THD when the source is supplying the load.

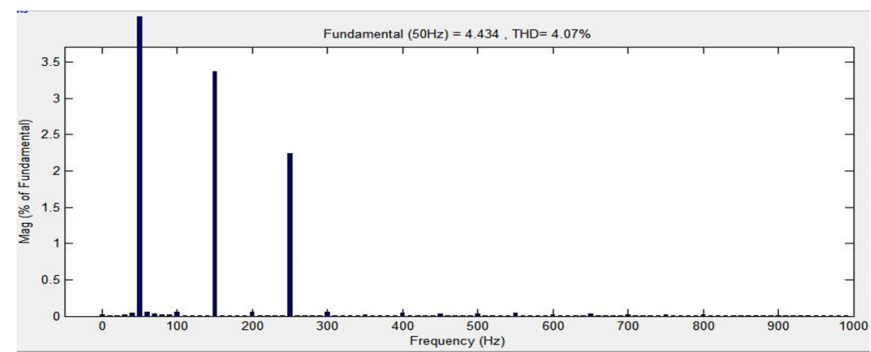

Fig. 19. THD when the PV system is operating. 


\section{CONCLUSION}

From the simulation results presented above, the following conclusions can be drawn:

- A single phase connected grid was designed under stable conditions. Depending upon variations in irradiations, MPPT operates to deliver power to the grid.

- The designed PV system is able to supply power in the occurrence of grid failure.

- The inverter supports the utility by injecting reactive current in order to avoid grid collapse.

- A PV system can be used as an independent source of power during supply outing conditions and to feed the load through the existing inverter by effectively maintaining the DC link voltage constant.

- The proposed controller handles loading conditions such as linear and nonlinear loads successfully.

\section{REFERENCES}

[1] D. Barater, E. Lorenzani, C. Concari, G. Franceschini, and G. Buticchi, "Recent advances in single-phase transformerless photovoltaic inverters," IET Renewable Power Generation, vol. 10, no. 2, pp. 260 273, 2016, doi: 10.1049/iet-rpg.2015.0101.

[2] R. Teodorescu, M. Liserre, and P. Rodriguez, Grid Converters for Photovoltaic and Wind Power Systems. Hoboken, NJ: Wiley-IEEE Press, 2007.

[3] H. Mahamudul, M. Saad, and M. Ibrahim Henk, "Photovoltaic System Modeling with Fuzzy Logic Based Maximum Power Point Tracking Algorithm," International Journal of Photoenergy, vol. 2013, Sep. 2013, Art. No. 762946, doi: 10.1155/2013/762946.

[4] A. Sangwongwanich and F. Blaabjerg, "Mitigation of Interharmonics in PV Systems With Maximum Power Point Tracking Modification," IEEE Transactions on Power Electronics, vol. 34, no. 9, pp. 8279-8282, Sep. 2019, doi: 10.1109/TPEL.2019.2902880.

[5] P. S. Gotekar, S. P. Muley, and D. P. Kothari, "Fuzzy Inference based control of single phase grid connected photovoltaic system," in 2019 Innovations in Power and Advanced Computing Technologies (i-PACT), llore, India, Mar. 2019, vol. 1, doi: 10.1109/i-PACT44901. 2019.8960041

[6] N. Vosoughi, S. H. Hosseini, and M. Sabahi, "Single-phase commongrounded transformer-less grid-tied inverter for PV application," IET Power Electronics, vol. 13, no. 1, pp. 157-167, 2020, doi: 10.1049/ietpel.2019.0364.

[7] S. S. Ghosh, K. S. Nathan, Y. P. Siwakoti, and T. Long, "Dual polarity DC-DC converter integrated grid-tied single-phase transformer less inverter for solar application," The Journal of Engineering, vol. 2019, no. 17 , pp. 3962-3966, 2019, doi: 10.1049/joe.2018.8041.

[8] A. Datta, R. Sarker, and I. Hazarika, "An Efficient Technique Using Modified $\mathrm{p}-\mathrm{q}$ Theory for Controlling Power Flow in a Single-Stage Single-Phase Grid-Connected PV System," IEEE Transactions on Industrial Informatics, vol. 15, no. 8, pp. 4635-4645, Aug. 2019, doi: 10.1109/TII.2018.2890197.

[9] A. Anurag, Y. Yang, and F. Blaabjerg, "Thermal Performance and Reliability Analysis of Single-Phase PV Inverters With Reactive Power Injection Outside Feed-In Operating Hours," IEEE Journal of Emerging and Selected Topics in Power Electronics, vol. 3, no. 4, pp. 870-880, Dec. 2015, doi: 10.1109/JESTPE.2015.2428432.

[10] Y. Yang, H. Wang, and F. Blaabjerg, "Reactive Power Injection Strategies for Single-Phase Photovoltaic Systems Considering Grid Requirements," IEEE Transactions on Industry Applications, vol. 50, no. 6, pp. 4065-4076, Nov. 2014, doi: 10.1109/TIA.2014.2346692.

[11] Y. Yang, F. Blaabjerg, and Z. Zou, "Benchmarking of Grid Fault Modes in Single-Phase Grid-Connected Photovoltaic Systems," IEEE
Transactions on Industry Applications, vol. 49, no. 5, pp. 2167-2176, Sep. 2013, doi: 10.1109/TIA.2013.2260512.

[12] N. Ikken, A. Bouknadel, A. Haddou, N.-E. Tariba, H. El omari, and H. El omari, "PLL Synchronization Method Based on Second-Order Generalized Integrator for Single Phase Grid Connected Inverters Systems during Grid Abnormalities," in 2019 International Conference on Wireless Technologies, Embedded and Intelligent Systems (WITS), Fez, Morocco, Apr. 2019, pp. 1-5, doi: 10.1109/WITS.2019.8723856.

[13] H. Z. Butt, M. Awon, and H. A. Khalid, "Performance Analysis of a Continuous and Discretized Second Order Generalized Integrator based Phase Lock Loop for Single Phase Grid Connected PV Systems," in 2018 International Conference on Power Generation Systems and Renewable Energy Technologies (PGSRET), Sep. 2018, pp. 1-6, doi: 10.1109/PGSRET.2018.8686038.

[14] A. K. Panda and N. Patnaik, "Combined Operation of a New Power Angle Control Unit Vector Template Based Unified Power Quality Conditioner and Fuel Cell Stack Supply with Effective Utilization of Shunt and Series Inverter," Electric Power Components and Systems, vol. 44, no. 18, pp. 2048-2058, Nov. 2016, doi: 10.1080/ 15325008.2016 .1210264 .

[15] A. Nouaiti, A. Mesbahi, A. Saad, M. Khafallah, and M. Reddak, "Realization of a Single-Phase Multilevel Inverter for Grid-Connected Photovoltaic System," Engineering, Technology \& Applied Science Research, vol. 8, no. 5, pp. 3344-3349, Oct. 2018.

[16] S. Krithiga and N. G. Ammasai Gounden, "Power electronic configuration for the operation of PV system in combined gridconnected and stand-alone modes," IET Power Electronics, vol. 7, no. 3, pp. 640-647, Mar. 2014, doi: 10.1049/iet-pel.2013.0107.

[17] P. Sarathi Subudhi and S. Krithiga, "PV and Grid interfaced Plug-in EV Battery Charger operating in P-VG, P-V and V-G Modes," International Journal of Recent Technology and Engineering, vol. 8, no. 2, pp. 34313443, Jul. 2019, doi: 10.35940/ijrte.B2680.078219.

[18] V. R. Reddy and S. E. S., "A Feedback-Based Passive Islanding Detection Technique for One-Cycle-Controlled Single-Phase Inverter Used in Photovoltaic Systems," IEEE Transactions on Industrial Electronics, vol. 67, no. 8, pp. 6541-6549, Aug. 2020, doi: 10.1109/ TIE.2019.2938464.

[19] S. A. Raza and J. Jiang, "A Benchmark Distribution System for Investigation of Residential Microgrids With Multiple Local Generation and Storage Devices," IEEE Open Access Journal of Power and Energy, vol. 7, pp. 41-50, 2020, doi: 10.1109/OAJPE.2019.2952812.

[20] L. H. Lam, T. D. H. Phuc, and N. H. Hieu, "Simulation Models For Three-Phase Grid Connected PV Inverters Enabling Current Limitation Under Unbalanced Faults," Engineering, Technology \& Applied Science Research, vol. 10, no. 2, pp. 5396-5401, Apr. 2020.

[21] M. Jamil, M. Rizwan, and D. P. Kothari, Grid Integration of Solar Photovoltaic Systems, 1st Edition. Boca Raton, FL: CRC Press, 2017.

[22] D. P. Kothari, K. C. Singal, and R. Ranjan, Renewable Energy Sources and Emerging Technologies, 2nd ed. New Delhi, India: PHI Learning Pvt. Ltd., 2011.

\section{AUTHORS PROFILE}

P. S. Gotekar completed her M.Tech from VNIT, Nagpur in 2001 and is a research scholar in the Priyadarshini College of Engineering, Nagpur. Her interest areas include power electronics, solar energy system and its applications.

S. P. Muley completed her Ph.D from VNIT, Nagpur in 2013. Her research areas include drives, control and renewable energy systems. She has 20 papers in international journals to her credit. She has over 25 years of experience in industry and research.

D. P. Kothari is a fellow IEEE, fellow institution of engineers, India and life member of the ISTE. He has authored over 60 books and presented 842 papers in international conferences and journals. 